\title{
Effect of thyme extract on quality characteristics of fresh-cut lettuce during storage
}

\author{
Hyeon-Jeong Lee ${ }^{1}$, Jin Luo ${ }^{1}$, Ji-Young Choi ${ }^{1}$, Kwang-Deog Moon ${ }^{1,2 *}$ \\ ${ }^{1}$ School of Food Science and Biotechnology, Kyungpook National University, Daegu 41566, Korea \\ ${ }^{2}$ Food and Bio-industry Research Institute, Kyungpook National University, Daegu 41566, Korea
}

\section{타임 추출물 처리가 신선편이 양상추의 저장 중 품질변화에 미치는 효과}

\author{
이현정 ${ }^{1} \cdot$ 루오진 $^{1} \cdot$ 최지영 ${ }^{1} \cdot$ 문광덕 $^{1,2 *}$ \\ 1경북대학교 식품공학부, ${ }^{2}$ 경북대학교 식품생물산업연구소
}

\begin{abstract}
The purpose of this study was to evaluate the quality of fresh-cut lettuce after a washing treatment with aqueous thyme extracts of differing concentration. Four different concentrations of thyme extract were employed: $0.001 \%$ (w/v, TEA), $0.005 \%(w / v$, TEB), $0.01 \%$ (w/v, TEC), $0.05 \%$ (w/v, TED), while distilled water was used as a control. Measurements of $\mathrm{O}_{2}$ concentration, $\mathrm{CO}_{2}$ concentration, total aerobic bacteria, $\mathrm{CIE} \mathrm{L}^{*}$, a, $\mathrm{b}^{*}$, browning index, total phenolic contents and enzymatic activities were investigated on day $0,1,3,5$, and 7 at $10^{\circ} \mathrm{C}$. The $\mathrm{O}_{2}$ concentration in TEB were higher than those in other samples during storage, and the $\mathrm{CO}_{2}$ concentration in TEB and TEC were significantly lower than in other samples on day 7. There was no significant difference in the total aerobic bacteria counts between treatments $(p<0.05)$. The samples treated with TEB and TEC showed higher $\mathbf{L}^{*}$ (lightness) values, but lower browning indexes, total phenolic compound levels, and enzymatic activities (polyphenol oxidase, peroxidase) than other samples during storage. Specifically, on day 7, the browning index of Cont reached 0.25 , while those in the TEB and TEC were about 0.15 . The $\mathrm{L}^{*}$ in Cont decreased from 69.50 to 58.92, while TEB and TEC were values of 65.61 and 63.20 , respectively. These results reveal that $0.005-0.01 \%$ thyme extract was effective as a washing treatment inhibited the browning of fresh-cut lettuce and is thus expected to be a useful natural extract for maintaining the quality of fresh-cut lettuce.
\end{abstract}

Key words : fresh-cut lettuce, thyme extract, phenolic contents, browning, enzymatic activity

\section{서 론}

경제의 발달과 사회의 변화에 따라 신선함과 경제성 및 건강식품이라는 인식과 더불어 편의성을 가진 fresh-cut 산 업은 매년 빠르게 성장하고 있다. 양상추(Lactuca sativa L.)는 fresh-cut 샐러드로서 세계적으로 널리 사용되며, fresh-cut 샐러드의 소비가 증가함에 따라 양상추의 소비

*Corresponding author. E-mail : kdmoon@knu.ac.kr Phone : 82-53-950-5773, Fax : 82-53-950-6772

Received 3 May 2018; Revised 21 June 2018; Accepted 22 June 2018.

Copyright (c) The Korean Society of Food Preservation. All rights reserved.
또한 증가하고 있다. fresh-cut 과채류는 비타민 A, thiamin, riboflavin, niacin, 비타민 C 등 다양한 비타민과 무기질을 함유하고 있으며(1), 양상추의 경우 일반적으로 세척·절단. 포장 과정을 거친 최소가공제품으로 이용되고 있어 조리. 가공한 다른 채소에 비해 더 많은 영양성분을 함유하고 있다(2). 소비자들이 fresh-cut 채소를 구매하는데 있어 안전 성 및 신선도가 문제가 되며, 이와 관련하여 채소의 외관, 품질, 안전성은 fresh-cut 제품을 구매하는데 중요한 고려사 항이 된다. 특히, fresh-cut 양상추의 경우 저장기간 동안 갈변현상이 안전 및 위생과 더불어 소비자들이 제품을 선택 하는데 있어 주요한 고려사항이다(3). 하지만 fresh-cut 양상 추는 일반적으로 절단 및 세척과정을 거쳐서 ready-to-eat 제품 형태로 유통되므로 저장기간 동안 자른 단면에서 효소 
적 갈변 및 품질 저하가 발생하고, 이는 결과적으로 원물 양상추에 비해 저장기간이 짧아지는 결과를 초래한다(4). fresh-cut 양상추의 안전성을 확보하고 효소적 갈변 및 품질 저하를 억제하기 위하여 염소수, 전해수, 오존수, 유기산, 환원제 등 다양한 화학물질을 이용한 연구(5,6)가 있다. 하 지만 소비자들의 건강에 대한 인식 변화로 이러한 화학물질 들을 기피함에 따라 식용작물 등에서 추출한 천연 물질에 관한 연구가 대두되고 있다.

허브는 항산화능이 뛰어난 원료로 자연유래의 항산화력 을 가진 식물은 산화에 의한 품질 저하를 억제하기 위해 유지 또는 유지를 포함한 식품에 이용되어 왔다(7). 허브의 종류 중 하나인 타임(thyme)은 Lamiaceae과에 속하고 정유 (essential oil)를 함유하고 있으며, 건조 타임을 이용한 친수 성 추출물은 생물학적 유효성분(특히, 폴리페놀)을 많이 함유한 것으로 알려져 있다(8). 타임 정유의 주요한 활성물 질은 페놀성 thymol과 cacacole로 알려져 있는데(9), 이 외에 도 타임 정유에는 60 여 가지의 화합물을 함유하고 있으며, 이로 인해 항산화성 및 항미생물성 특징이 나타난다는 보고 가 있다(10). 타임을 식품에 이용한 연구로는, 헥산 및 $\mathrm{CO}_{2}$ 를 이용하여 추출한 타임 추출물의 난황 및 계란에서의 항산화 효과, 에탄올 추출물에서 총 페놀화합물과 항산화 활성 효과 및 타임 정유가 연어의 유통기한에 미치는 영향 등이 있다(11-14). 또한 수용성 타임 추출물의 항염증, 항응 고 및 항산화효과에 관한 연구가 있다(15). 따라서 본 연구 에서는 수용성 타임 추출물을 전처리로서 washing 처리한 fresh-cut 양상추에 있어서 갈변, 항산화, 효소활성 및 미생 물 변화에 미치는 영향을 확인하고자 하였다.

\section{재료 및 방법}

\section{실험재료}

양상추는 대구에 위치한 마트에서 무작위 구매하였으며, 상태가 건전한 양상추를 선별하여 세척한 후 실험에 이용하 였다. 타임은 건조된 분말형태의 제품(Eunjin Co., Yeoncheon, Korea)을 구매하였다.

\section{타임 추출물의 제조}

타임 가루 $10 \mathrm{~g}$ 과 ethanol $(80 \%, \mathrm{v} / \mathrm{v}) 190 \mathrm{~g}$ 을 혼합하여 $65^{\circ} \mathrm{C}$ 수욕상에서 5 시간 동안 추출한 후, filter paper(No.2, Whatman, Maidstone, UK)를 이용하여 여과하였다. 여과한 액의 ethanol을 제거한 후 증류수에 희석하여 실험에 사용 하였다. 예비실험을 통하여 희석 농도를 결정하였으며, 증 류수로 처리한 시료(Cont)을 대조구로 하고, $0.001 \%(\mathrm{w} / \mathrm{v}$, TEA), $0.005 \%(\mathrm{w} / \mathrm{v}, \mathrm{TEB}), 0.01 \%(\mathrm{w} / \mathrm{v}, \mathrm{TEC})$ 및 $0.05 \%(\mathrm{w} / \mathrm{v}$, TED)의 타임 추출물 희석액을 제조하였다.

\section{전처리조건 및 저장}

선별한 양상추의 겉잎은 제거한 후 공기 접촉에 의한 갈변을 최소화하기 위하여 양상추를 물에 담근 채 수욕상에 서 약 $30 \times 20 \mathrm{~mm}$ 크기로 절단하였다. 처리한 양상추는 미리 제조한 5 종의 증류수 및 타임 추출물 희석액에 3 분 동안 침지하고, 즉시 3 분 동안 증류수를 이용하여 헹굼 세척을 실시하였다. 헹굼 세척이 끝난 양상추는 $0.03 \mathrm{~mm}$ 두께의 $\mathrm{PP}$ (polypropylene) film bag $(300 \times 200 \mathrm{~mm})$ 을 이용하여 열접 합 포장하였다. 각 포장에 사용한 양상추는 약 $50 \mathrm{~g}$ 이었으 며, $10^{\circ} \mathrm{C}$ 에서 7 일간 저장하면서 $0,1,3,5$, 및 7 일 간격으로 품질 특성을 분석하였다.

\section{포장 내 기체 조성 분석}

PP film 내부의 기체 조성은 DualTrak oxygen/carbon dioxide analyzer(Model 902D, Quantek Instruments, Northboro, $\mathrm{MA}, \mathrm{USA}$ )를 이용하여 산소와 이산화탄소 농도를 측정하 였다.

\section{색도 측정}

저장 중 양상추의 색도 측정에는 백색판 $\left(\mathrm{L}^{*}=97.79\right.$, $\left.a^{*}=-0.38, b^{*}=2.05\right)$ 으로 보정된 Colorimeter(CR-400, Konica Minolta Co., Tokyo, Japan)를 이용하였다. 시료를 15 회 측정 하여 $\mathrm{L}^{*}$ (lightness), $\mathrm{a}^{*}$ (redness) 및 $\mathrm{b}^{*}$ (yellowness) 값으로 나 타내었다.

\section{갈변도 측정}

저장 중 양상추의 갈변도는 Jung 등(16)의 방법을 변형하 여 사용하였다. 양상추의 절단면으로부터 $1 \mathrm{~cm}$ 폭으로 절 단하여 취한 시료 $2 \mathrm{~g}$ 에 증류수 $40 \mathrm{~mL}$ 과 $10 \%$ trichloroacetic acid $10 \mathrm{~mL}$ 을 가하고 마쇄한 후 $35^{\circ} \mathrm{C}$ 에서 2시간 동안 추출 하였다. 추출한 액을 여과(No.2, Whatman)한 후 UV-visible spectrophotometer(Evolution 201, Thermo Fisher Scientific Inc., Weltham, MA, USA)를 이용하여 $420 \mathrm{~nm}$ 에서 측정한 흡광도로 나타내었다.

\section{총 페놀 함량 측정}

양상추의 총 페놀 함량은 Folin-Ciocalteu 방법(17)을 변 형하여 측정하였다. 양상추 $5 \mathrm{~g}$ 과 ethanol $(80 \%, \mathrm{v} / \mathrm{v}) 100$ $\mathrm{mL}$ 을 마쇄하고 여과(No.2, Whatman)하여 추출액을 준비 하였다. 준비한 추출액 $1 \mathrm{~mL}$ 과 Folin-Ciocalteu's reagent (JUNSEI Chemical Co., Ltd., Tokyo, Japan) $1 \mathrm{~mL}$ 을 혼합하 여 암소에서 15 분간 반응시켰다. 그 후 $10 \% \mathrm{Na}_{2} \mathrm{CO}_{3}$ 용액 $1 \mathrm{~mL}$ 을 가하여 암소에서 1시간 방치한 다음 UV-visible spectrophotometer(Evolution 201, Thermo Fisher Scientific Inc.)를 이용하여 $760 \mathrm{~nm}$ 에서 흡광도를 측정하고 catechin (Sigma-Aldrich Chemical Co., St. Louis, MO, USA)을 표준 용액으로 총 페놀 함량을 계산하였다. 


\section{Polyphenol oxidase(PPO) 및 peroxidase(POD) 활성 측정}

양상추의 저장 중 $\mathrm{PPO}$ 및 $\mathrm{POD}$ 활성 변화를 측정하기 위해 각각 Rico 등(18)과 Yang 등(19)의 방법을 변형하여 실험하였다. 양상추 $10 \mathrm{~g}$ 과 PVPP(polyvinylpolypyrrolidone, Sigma-Aldrich Chemical Co.) $5 \mathrm{~g}$ 을 포함한 $0.2 \mathrm{M}$ sodium phosphate buffer(pH 7.0) $90 \mathrm{~mL}$ 을 균질화하고 $10,000 \times \mathrm{g}$ 에 서 15 분간 원심분리하여 얻은 상징액을 조효소액으로 사용 하였다. 조효소액 $0.8 \mathrm{~mL}$ 과 $0.05 \mathrm{M}$ sodium phosphate buffer(pH 7.0)을 이용하여 제조한 $0.02 \mathrm{M}$ catechol 용액 $2.4 \mathrm{~mL}$ 을 반응시킨 후 UV-visible spectrophotometer(Evolution 201, Thermo Fisher Scientific Inc.)를 이용하여 $420 \mathrm{~nm}$ 에서 흡광도를 측정하고, 1 분당 0.01 의 흡광도 변화량을 1 unit로 하여 unit/mg으로 PPO 활성을 나타내었다. 또한 POD 활성 은 조효소액 $0.2 \mathrm{~mL}$ 과 $25 \mathrm{mM}$ guaiacol(Sigma-Aldrich Chemical Co.) 용액 $2.8 \mathrm{~mL}$ 을 반응시킨 후 UV-visible spectrophotometer(Evolution 201, Thermo Fisher Scientific Inc.)를 이용하여 $470 \mathrm{~nm}$ 에서 흡광도를 측정하고, 1 분당 0.01 의 흡광도 변화량을 1 unit로 하여 unit/mg으로 나타내 었다.

\section{호기성 총 세균 측정}

양상추 저장 중 호기성 총 세균 변화를 측정하기 위하여 식품공전(20)에 따라 실시하였다. 양상추 $25 \mathrm{~g}$ 과 $0.1 \%$ pepton water $225 \mathrm{~mL}$ 를 멸균백에 넣고 stomacher (Bagmixer ${ }^{\circledR} 400 C C$, Interscience, St. Nom, France)를 이용하 여 6분간 혼합하였다. 혼합액 $1 \mathrm{~mL}$ 를 plate count agar(BD Difco Lab., Sparks, MD, USA)와 혼합하여 $35^{\circ}$ 에서 48-72 시간 배양한 후 집락을 계수하고, $\log \mathrm{CFU} / \mathrm{g}$ 으로 나타내었 다.

\section{통계처리}

실험은 3회 이상 반복 측정하여 평균과 표준편차로 나타 내었다. 또한 유의성 검정을 위하여 SPSS 24 program을 이용하여 $p<0.05$ 수준에서 Duncan's multiple range test를 실시하였다.

\section{결과 및 고찰}

\section{포장 내 기체 조성 변화}

타임 추출물을 처리한 양상추의 저장 중 포장 내 기체조 성 변화는 Fig. 1에 나타내었다. 저장 3 일째까지 포장 내 $\mathrm{O}_{2}$ 함량은 급격하게 감소하였고 저장 1 일 및 7 일에는 처리 구별 $\mathrm{O}_{2}$ 함량의 유의적인 차이는 없었으나, 저장 3 일 및 5 일에는 타임 추출물 무처리구(Cont)가 타임 추출물 처리구 에 비해 유의적으로 낮은 $\mathrm{O}_{2}$ 함량으로 나타났다. 전반적으
로 $\mathrm{TEB}$ 처리구의 $\mathrm{O}_{2}$ 함량은 높게 측정되었다. 포장 내 $\mathrm{CO}_{2}$ 함량은 저장 5 일째까지 증가하였고, 저장 7 일째 TEB 및 $\mathrm{TEC}$ 처리구의 $\mathrm{CO}_{2}$ 함량은 각각 $0.87 \%$ 및 $0.80 \%$ 로 다른 구에 비해 유의적으로 낮은 값으로 나타났다. 포장 내 기체 조성의 변화는 시료간의 호흡률을 평가할 수 있는 방법으 로, 산소 함량은 효소활성과 같은 품질특성에 영향을 미칠 수 있다고 알려져 있다(16). 낮은 $\mathrm{O}_{2}$ 함량 및 높은 $\mathrm{CO}_{2}$ 함량 의 조건은 modified atmosphere packaging(MAP)의 원리로 알려져 있지만, 지나치게 낮은 수준의 $\mathrm{O}_{2}$ 함량은 acetaldehyde 형성 및 이취를 발생시키므로 이를 억제하기 위해 최소 산소 농도가 $1 \%$ 이상이어야 한다(21). $\mathrm{Kim}$ 등(22)의 연구에 서도 저장기간 동안 $\mathrm{CO}_{2}$ 의 꾸준한 감소가 나타나 본 연구에 서와 유사한 경향으로 나타났다.
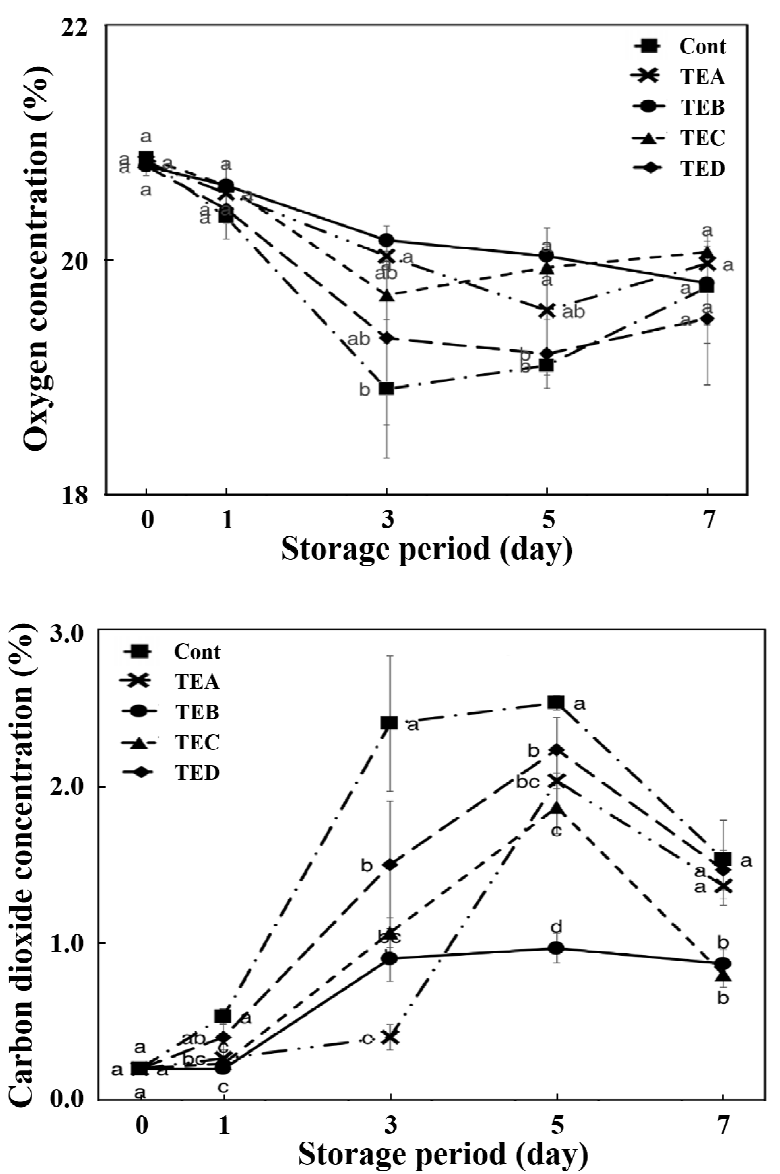

Fig. 1. Changes in the oxygen and carbon dioxide concentration of treated fresh-cut lettuce during storage.

Cont, distilled water; TEA, $0.001 \%(\mathrm{w} / \mathrm{v})$ thyme extract; TEB, $0.005 \%(\mathrm{w} / \mathrm{v})$ thyme extract; TEC, $0.01 \%(\mathrm{w} / \mathrm{v})$ thyme extract; TED, $0.05 \%(\mathrm{w} / \mathrm{v})$ thyme extract.

Value represent means $\pm \mathrm{SD}(\mathrm{n}=3)$. Bar with different letters are significant statistical difference $(\mathrm{p}<0.05)$ by Duncan's multiple range test.

색도 변화

타임 추출물을 처리한 양상추의 저장기간 동안 색 변화 는 Table 1에 나타내었다. 모든 처리구에서 저장기간 동안 
Table 1. Changes in the CIE $L^{*}, a^{*}$, and $b^{*}$ values of fresh-cut lettuce treated with different thymine extract during storage

\begin{tabular}{|c|c|c|c|c|c|c|}
\hline \multirow{2}{*}{$\begin{array}{l}\text { Storage period } \\
\text { (day) }\end{array}$} & \multirow{2}{*}{$\begin{array}{l}\text { Color } \\
\text { value }\end{array}$} & \multicolumn{5}{|c|}{ Treatment ${ }^{1)}$} \\
\hline & & Cont & TEA & TEB & TEC & TED \\
\hline \multirow{3}{*}{0} & $\mathrm{~L}^{*}$ & $69.50 \pm 4.04^{22)}$ & $69.50 \pm 5.78^{\mathrm{a}}$ & $69.50 \pm 2.96^{\mathrm{a}}$ & $69.57 \pm 3.86^{\mathrm{a}}$ & $69.41 \pm 3.71^{\mathrm{a}}$ \\
\hline & $a^{*}$ & $-1.99 \pm 0.38^{\mathrm{a}}$ & $-2.03 \pm 0.51^{\mathrm{a}}$ & $-1.98 \pm 0.58^{\mathrm{a}}$ & $-1.94 \pm 0.44^{\mathrm{a}}$ & $-2.11 \pm 0.31^{\mathrm{a}}$ \\
\hline & $b^{*}$ & $4.97 \pm 0.97^{\mathrm{a}}$ & $5.13 \pm 1.04^{\mathrm{a}}$ & $4.98 \pm 1.12^{\mathrm{a}}$ & $5.14 \pm 0.97^{\mathrm{a}}$ & $5.03 \pm 2.39^{\mathrm{a}}$ \\
\hline \multirow{3}{*}{1} & $\mathrm{~L}^{*}$ & $68.40 \pm 3.96^{\mathrm{a}}$ & $68.46 \pm 4.90^{\mathrm{a}}$ & $68.12 \pm 5.24^{a}$ & $68.08 \pm 6.63^{\mathrm{a}}$ & $68.41 \pm 7.85^{\mathrm{a}}$ \\
\hline & $a^{*}$ & $-2.19 \pm 0.80^{\mathrm{a}}$ & $-2.20 \pm 0.69^{\mathrm{a}}$ & $-2.13 \pm 0.41^{\mathrm{a}}$ & $-2.14 \pm 0.31^{\mathrm{a}}$ & $-2.03 \pm 1.02^{\mathrm{a}}$ \\
\hline & $b^{*}$ & $4.91 \pm 1.72^{\mathrm{a}}$ & $4.99 \pm 1.68^{\mathrm{a}}$ & $4.90 \pm 1.02^{\mathrm{a}}$ & $4.92 \pm 0.82^{\mathrm{a}}$ & $5.06 \pm 2.36^{a}$ \\
\hline \multirow{3}{*}{3} & $\mathrm{~L}^{*}$ & $64.44 \pm 4.95^{\mathrm{a}}$ & $66.00 \pm 2.56^{\mathrm{a}}$ & $67.10 \pm 1.83^{\mathrm{a}}$ & $67.15 \pm 2.56^{\mathrm{a}}$ & $65.60 \pm 5.73^{\mathrm{a}}$ \\
\hline & $a^{*}$ & $-2.55 \pm 0.76^{\mathrm{a}}$ & $-1.20 \pm 1.03^{\mathrm{a}}$ & $-2.09 \pm 0.25^{\mathrm{a}}$ & $-1.95 \pm 0.72^{\mathrm{a}}$ & $-2.24 \pm 0.41^{\mathrm{a}}$ \\
\hline & $b^{*}$ & $6.52 \pm 1.57^{\mathrm{a}}$ & $4.84 \pm 2.79^{\mathrm{a}}$ & $5.38 \pm 0.77^{\mathrm{a}}$ & $5.26 \pm 1.31^{\mathrm{a}}$ & $5.67 \pm 1.36^{\mathrm{a}}$ \\
\hline \multirow{3}{*}{5} & $\mathrm{~L}^{*}$ & $59.97 \pm 5.27^{\mathrm{c}}$ & $62.96 \pm 4.53^{\text {abc }}$ & $65.87 \pm 4.62^{\mathrm{a}}$ & $64.00 \pm 3.86^{\mathrm{ab}}$ & $60.57 \pm 4.61^{\mathrm{bc}}$ \\
\hline & $a^{*}$ & $-1.68 \pm 0.75^{\mathrm{a}}$ & $-1.74 \pm 0.62^{\mathrm{a}}$ & $-1.79 \pm 0.66^{\mathrm{a}}$ & $-1.86 \pm 0.46^{a}$ & $-1.94 \pm 0.33^{\mathrm{a}}$ \\
\hline & $b^{*}$ & $5.31 \pm 1.52^{\mathrm{a}}$ & $5.16 \pm 0.93^{\mathrm{a}}$ & $5.11 \pm 1.25^{\mathrm{a}}$ & $4.96 \pm 0.69^{\mathrm{a}}$ & $5.11 \pm 0.67^{\mathrm{a}}$ \\
\hline \multirow{3}{*}{7} & $\mathrm{~L}^{*}$ & $58.92 \pm 5.62^{\mathrm{c}}$ & $62.30 \pm 2.91^{\mathrm{abc}}$ & $65.61 \pm 5.66^{\mathrm{a}}$ & $63.20 \pm 6.78^{\mathrm{ab}}$ & $61.33 \pm 2.25^{\mathrm{bc}}$ \\
\hline & $a^{*}$ & $-0.28 \pm 2.19^{\mathrm{a}}$ & $-0.36 \pm 1.48^{\mathrm{a}}$ & $-0.91 \pm 1.28^{\mathrm{a}}$ & $-0.76 \pm 1.58^{\mathrm{a}}$ & $-0.16 \pm 1.69^{a}$ \\
\hline & $b^{*}$ & $10.55 \pm 4.42^{\mathrm{a}}$ & $8.86 \pm 3.34^{\mathrm{ab}}$ & $7.25 \pm 2.98^{b}$ & $8.48 \pm 2.86^{\mathrm{ab}}$ & $10.33 \pm 4.33^{\mathrm{a}}$ \\
\hline
\end{tabular}

${ }^{1)}$ Cont, distilled water; TEA, $0.001 \%(\mathrm{w} / \mathrm{v})$ thyme extract; TEB, $0.005 \%(\mathrm{w} / \mathrm{v})$ thyme extract; TEC, $0.01 \%(\mathrm{w} / \mathrm{v})$ thyme extract; TED, $0.05 \%(\mathrm{w} / \mathrm{v})$ thyme extract.

${ }^{2)}$ Value represent means $\pm \mathrm{SD}(\mathrm{n}=15)$. Different letters in the same row indicate significant statistical difference $(\mathrm{p}<0.05)$ by Duncan's multiple range test.

$\mathrm{L}^{\star}$ 값은 감소하였고, $\mathrm{a}^{*}$ 값 및 $\mathrm{b}^{*}$ 값은 증가하는 경향을 보였다. Redness를 나타내는 a* 값은 저장기간 동안 모든 처리구에서 타임 추출물 희석액의 농도에 따른 유의적 차이 는 보이지 않았으나, yellowness를 나타내는 $\mathrm{b}^{*}$ 값은 저장 7일째 Cont 및 TED 처리구에서 TEB 처리구에 비해 유의적 으로 높은 값으로 나타났다. 또한 lightness를 나타내는 $\mathrm{L}^{*}$ 값의 경우, 저장 5 일 및 7 일에 Cont 처리구의 경우 다른 처리구에 비해 낮았으나, TEB 처리구의 경우 다른 처리구 에 비해 유의적으로 높은 값으로 나타나 다른 처리구와 비교했을 때 TEB 처리구가 더 밝음을 확인할 수 있었다.

\section{갈변도 변화}

양상추의 갈변은 품질의 저하를 일으키며, fresh-cut 양상 추에서 유통기한과 시장성을 유추할 수 있는 요인이 된다 (23). 타임 추출물을 처리한 fresh-cut 양상추의 저장기간 동안 갈변도를 측정한 결과는 Fig. 2 와 같다. 저장기간 동안 갈변도는 모든 처리구에서 증가하였으며, 전반적으로 저장 기간 동안 TEB 및 TEC 처리구의 흡광도 값이 유의적으로 낮아 갈변 진행이 억제되었음을 알 수 있었다. Cont 처리구 의 경우 저장기간 동안 다른 처리구에 비해 유의적으로 높은 흡광도 값을 보여, 타임 추출물 처리구가 무처리구에 비해 양상추의 갈변 억제에 효과가 있음을 확인하였다.

\section{총 페놀 함량 변화}

폴리페놀 함량은 항산화 활성의 척도가 될 수 있는 반면

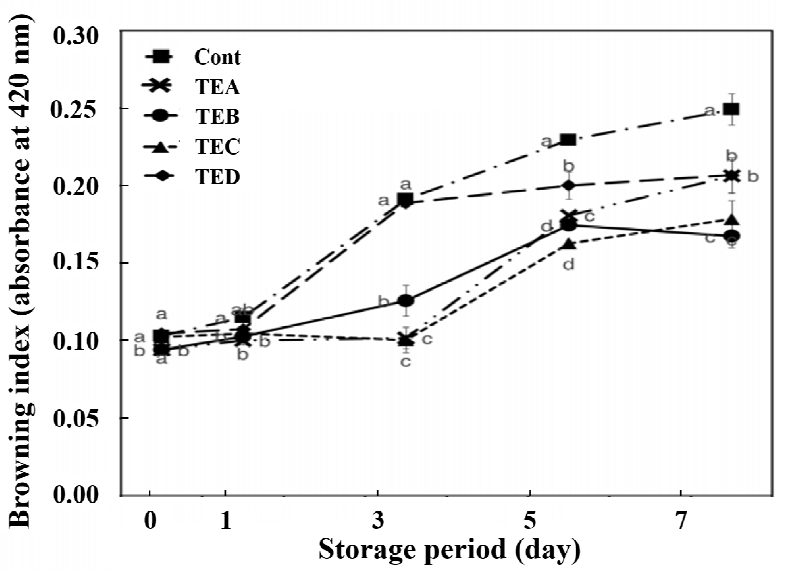

Fig. 2. Changes in the browning index of fresh-cut lettuce treated with different thymine extract during storage.

Cont, distilled water; TEA, $0.001 \%(\mathrm{w} / \mathrm{v})$ thyme extract; TEB, $0.005 \%(\mathrm{w} / \mathrm{v})$ thyme extract; TEC, $0.01 \%$ (w/v) thyme extract; TED, $0.05 \%$ (w/v) thyme extract. Value represent means $\pm S D(n=3)$. Bar with different letters are significant statistical difference $(p<0.05)$ by Duncan's multiple range test.

에 효소적 갈변 반응의 기질이 될 수 있다(24). 타임 추출물 을 처리한 양상추의 저장기간에 따른 총 페놀 함량은 Fig. 3 에 나타내었다. 저장 0 일에 비해 저장 7 일에 총 페놀 함량 은 증가하였으며, 저장기간 동안 무처리구에 비해 타임 추 출물 처리구의 총 페놀 함량이 유의적으로 낮게 나타났다. 또한 타임 추출물 처리구 중 TEB 처리구의 총 페놀함량은 저장기간 동안 다른 처리구에 비해 전반적으로 낮음을 알 수 있었다. 절단, 균열 및 파손과 같은 양상추에서의 상처는 
페놀 화합물의 생성과 갈변을 증가시키는 대사 경로를 촉진 하는 효소의 합성을 유도하는 신호를 생성할 수 있다(25). 또한 Kang과 Saltveit(26)의 연구에서 양상추의 상처와 저장 시간에 따라 총 페놀 함량 및 항산화 활성이 증가하는 것을 확인하였는데, 이러한 결과는 본 연구와 유사한 경향으로 나타났다.

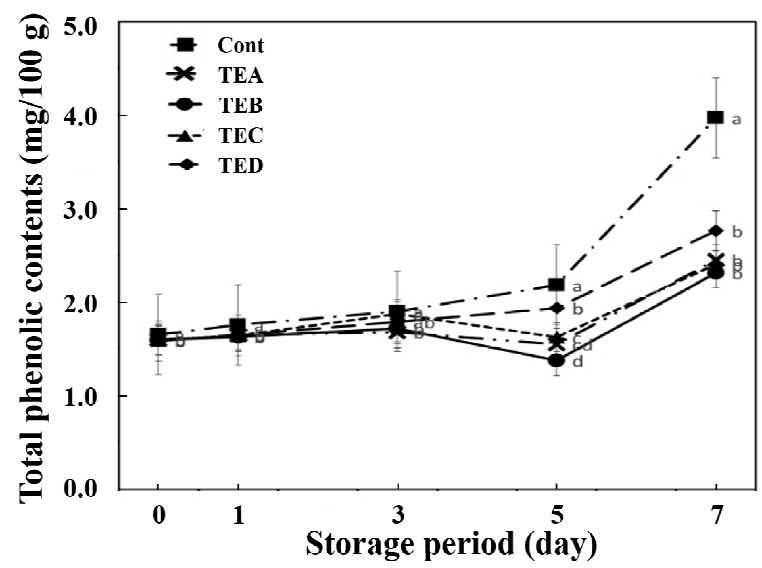

Fig. 3. Changes in the total phenolic contents of fresh-cut lettuce treated with different thymine extract during storage.

Cont, distilled water; TEA, $0.001 \%(\mathrm{w} / \mathrm{v})$ thyme extract; TEB, $0.005 \%(\mathrm{w} / \mathrm{v})$ thyme extract; TEC, $0.01 \%(\mathrm{w} / \mathrm{v})$ thyme extract; TED, $0.05 \%(\mathrm{w} / \mathrm{v})$ thyme extract. Value represent means $\pm S D(n=3)$. Bar with different letters are significant statistical difference $(\mathrm{p}<0.05)$ by Duncan's multiple range test.

\section{Polyphenol oxidase(PPO) 및 peroxidase(POD) 활성 변화}

$\mathrm{PPO}$ 및 $\mathrm{POD}$ 는 효소적 갈변과 관련된 대표적인 효소로 알려져 있으며(27), 효소적 갈변 측정에 중요한 지표로 이용 된다. 타임 추출물을 처리한 양상추의 저장기간에 따른 $\mathrm{PPO}$ 및 $\mathrm{POD}$ 활성의 변화는 Fig. 4 와 같다. 저장 0 일의 $\mathrm{PPO}$ 활성은 처리구에 따른 유의적인 차이가 없었으나, 저 장 1 일째부터 저장기간 동안 타임 추출물 무처리구의 $\mathrm{PPO}$ 활성이 타임 추출물 처리구의 경우보다 유의적으로 높게 나타났다. PPO 활성은 저장기간 동안 지속적으로 증가하였 으며, 저장 7일째 TEB 처리구의 $\mathrm{PPO}$ 활성이 가장 낮게 나타났다. $\mathrm{POD}$ 의 활성은 $\mathrm{PPO}$ 와 유사한 경향으로 나타났 는데, 저장기간 동안 $\mathrm{POD}$ 활성은 지속적으로 증가하였으 며, 타임 추출물 무처리구의 POD 활성이 타임 추출물 처리 구보다 높게 나타났다. 또한 저장 7일째 TEC 처리구의 POD 활성은 다른 구에 비해 유의적으로 낮게 나타났다.

앞서 확인한 색도 및 갈변도 등의 항목에서 TEB 처리구 의 경우 갈변 저해에 가장 효과적으로 나타났는데, $\mathrm{PPO}$ 및 $\mathrm{POD}$ 활성 역시 TEB 처리구가 유의적으로 낮은 활성으 로 나타났다. 따라서 각 항목이 서로 상관성이 있을 것으로 추정된다. Ryu 등(28)의 최소 가공 양송이버섯의 연구 및 Kim 등(29)의 신선편이 양상추 연구에서 색도 갈변도, PPO 활성의 항목이 서로 높은 상관관계가 성립됨을 보고한 바
있어, 본 연구에서의 추정과 유사한 것으로 나타났다.
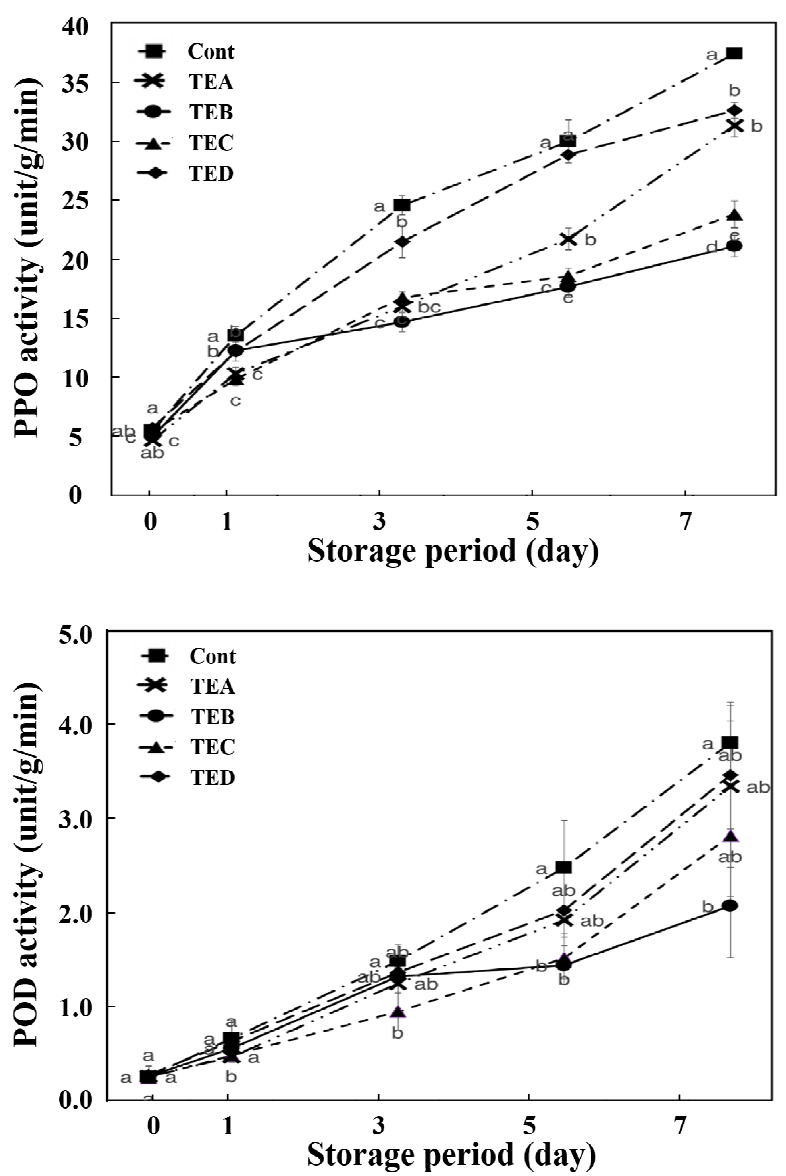

Fig. 4. Changes in the PPO activity (A) and POD activity (B) of fresh-cut lettuce treated with different thymine extract during storage.

Value represent means $\pm \mathrm{SD}(\mathrm{n}=3)$. Bar with different letters are significant statistical difference $(p<0.05)$ by Duncan's multiple range test.

Cont, distilled water; TEA, $0.001 \%(\mathrm{w} / \mathrm{v})$ thyme extract; TEB, $0.005 \%$ (w/v) thyme extract; TEC, $0.01 \%(\mathrm{w} / \mathrm{v})$ thyme extract; TED, $0.05 \%(\mathrm{w} / \mathrm{v})$ thyme extract.

\section{호기성 총 세균의 변화}

최소가공 채소의 경우 약산성 $(\mathrm{pH}$ 5.8-6.0)을 띄므로 미생 물학적 안전성에 대한 연구가 필요하다. 저장기간에 따른 타임 추출물 처리 양상추의 호기성 총 세균의 변화는 Table 2 에 나타내었다. 타임 추출물을 처리한 직후인 저장 0 일 호기성 총 세균은 4.22 $\pm 0.09-4.27 \pm 0.11 \log \mathrm{CFU} / \mathrm{g}$ 이었으며, 저장 7일에는 6.25 $\pm 0.07-3.67 \pm 0.07 \log \mathrm{CFU} / \mathrm{g}$ 으로 나타나 저장기간에 따른 호기성 총 세균의 지속적인 증가를 알 수 있었다. Bagamboula 등의 연구(30)에서 $0.1 \%$ 및 $0.05 \%$ 타임 정유를 적용하였을 때 Enterobacteriaceae 및 호기성 총 세균의 저해효과가 있다고 보고하였으며, Singh 등의 연구(31)에서도 $1 \%$ 및 $0.1 \%$ 타임 정유를 적용하였을 때 E. coli $\mathrm{O} 157: \mathrm{H} 7$ 의 감소효과는 있었으나 $0.01 \%$ 타임 정유를 적용하였을 때의 미생물 감소효과는 없었다고 보고하였다. 
또한 Shigenobu와 Kazuhiko의 연구(32)에서는 산성의 전기 분해수를 처리한 fresh-cut 양상추가 수돗물을 처리한 fresh-cut 양상추에 비해 $\mathrm{O}_{2}$ 함량의 높은 감소율, $\mathrm{CO}_{2}$ 함량의 높은 증가율 및 낮은 미생물수를 보고하였다. 하지만 본 연구에서는 타임 추출물 무처리구(Cont)가 타임 추출물 처 리구에 비해 높은 $\mathrm{O}_{2}$ 함량 및 낮은 $\mathrm{CO}_{2}$ 함량으로 나타났음 에도 불구하고 타임 추출물 희석액 처리에 따른 호기성 총 세균의 유의적인 차이는 나타나지 않았는데, 이는 처리 한 타임 추출물의 농도가 $0.005-0.05 \%$ 로 낮은 것이 기인한 것이라 추정된다.

Table 2. Changes in the total aerobic bacteria of fresh-cut lettuce treated with different thymine extract during storage

\begin{tabular}{cccccc}
\hline \multirow{2}{*}{ Day } & \multicolumn{5}{c}{ Treatment $^{\mathrm{l}}$} \\
\cline { 2 - 6 } & Con & TEA & TEB & TEC & TED \\
\hline 0 & $4.24 \pm 0.12^{\mathrm{a} 2)}$ & $4.25 \pm 0.09^{\mathrm{a}}$ & $4.26 \pm 0.07^{\mathrm{a}}$ & $4.22 \pm 0.09^{\mathrm{a}}$ & $4.27 \pm 0.11^{\mathrm{a}}$ \\
1 & $4.35 \pm 0.67^{\mathrm{a}}$ & $4.35 \pm 0.16^{\mathrm{a}}$ & $4.38 \pm 0.11^{\mathrm{a}}$ & $4.37 \pm 0.09^{\mathrm{a}}$ & $4.45 \pm 0.09^{\mathrm{a}}$ \\
3 & $4.64 \pm 0.12^{\mathrm{a}}$ & $4.69 \pm 0.12^{\mathrm{a}}$ & $4.65 \pm 0.96^{\mathrm{a}}$ & $4.67 \pm 0.13^{\mathrm{a}}$ & $4.60 \pm 0.10^{\mathrm{a}}$ \\
5 & $5.24 \pm 0.07^{\mathrm{a}}$ & $5.40 \pm 0.14^{\mathrm{a}}$ & $5.44 \pm 0.19^{\mathrm{a}}$ & $5.38 \pm 0.16^{\mathrm{a}}$ & $5.32 \pm 0.18^{\mathrm{a}}$ \\
7 & $6.26 \pm 0.13^{\mathrm{a}}$ & $6.37 \pm 0.07^{\mathrm{a}}$ & $6.40 \pm 0.07^{\mathrm{a}}$ & $6.25 \pm 0.07^{\mathrm{a}}$ & $6.36 \pm 0.07^{\mathrm{a}}$ \\
\hline
\end{tabular}

${ }^{1)}$ Cont, distilled water; TEA, $0.001 \%$ (w/v) thyme extract; TEB, $0.005 \%$ (w/v) thyme extract; TEC, $0.01 \%(\mathrm{w} / \mathrm{v})$ thyme extract; TED, $0.05 \%(\mathrm{w} / \mathrm{v})$ thyme extract.

${ }^{2}$ Value represent means $\pm \mathrm{SD}(\mathrm{n}=15)$. Different letters in the same row indicate significant statistical difference $(\mathrm{p}<0.05)$ by Duncan's multiple range test.

\section{요 약}

본 연구에서는 물을 이용한 타임 추출물을 처리하여 fresh-cut 양상추의 효소적 갈변 저해 효과를 확인하기 위하 여 증류수(Cont), $0.001 \%$ 타임 추출물(TEA), $0.005 \%$ 타임 추출물(TEB), $0.01 \%$ 타임 추출물(TEC) 및 $0.05 \%$ 타임 추출 물(TED)을 침지액으로 처리하였다. 포장 내 기체 조성의 분석 결과 전반적으로 $\mathrm{TEB}$ 처리구의 $\mathrm{O}_{2}$ 함량은 높게 측정 되었고, 저장 7일째 TEB 및 TEC 처리구의 $\mathrm{CO}_{2}$ 함량은 다른 처리구에 비해 유의적으로 낮게 측정되었다. TEB 처 리구의 $\mathrm{L}^{*}$ 값은 다른 처리구에 비해 유의적으로 높은 값으 로 나타났다. 전반적으로 저장기간 동안 $\mathrm{TEB}$ 및 $\mathrm{TEC}$ 처리 구의 갈변도가 유의적으로 낮게 나타났으며, Cont 처리구 의 경우 저장기간 동안 다른 처리구에 비해 유의적으로 높은 갈변도를 보였다. 저장기간에 따라 총 페놀 함량, $\mathrm{PPO}$ 및 $\mathrm{POD}$ 활성은 지속적으로 증가하는 경향을 보였고, 저장 기간 동안 타임 추출물 처리구에 비해 타임 추출물 무처리 구의 총 페놀 함량, PPO 및 $\mathrm{POD}$ 활성이 더 낮게 측정되었다. 타임 추출물 처리구 중 특히 TEB 처리구의 총 페놀 함량, $\mathrm{PPO}$ 및 POD 활성이 유의적으로 낮았다. 호기성 총 세균 실험 결과 저장기간에 따른 증가는 있었으나, 타임 추출물
처리구별 호기성 총 세균의 유의적인 차이는 나타나지 않았 다. 이러한 결과들로 보아 타임 추출물 처리가 항균보다 효소적 갈변 억제에 더 효과가 있음을 확인할 수 있었다. 특히 타임 추출물 $0.005 \%$ 처리구의 경우 갈변 저해 효과가 뛰어나 품질 유지에 긍정적인 영향을 줄 수 있으므로, fresh-cut 양상추의 전처리, 가공 및 유통에 있어서 효과적인 방법으로 사용될 수 있을 것이라 기대된다.

\section{감사의 글}

본 연구는 농림축산식품부의 재원으로 농림식품기술기 획평가원의 고부가가치식품기술개발사업의 지원을 받아 연구되었습니다(316068-03).

\section{References}

1. Klein BP (1987) Nutritional consequences of minimal processing of fruits and vegetables. J Food Qual, 10, 179-193

2. Kim MJ, Moon YY, Tou JC, Mou B, Waterland NL (2016) Nutritional value, bioactive compounds and health benefits of lettuce (Lactuca sativa L.). J Food Compos Anal, 49, 19-34

3. Mo CY, Kim GY, Kim MS, Lim JG, Lee KJ, Lee WH, Cho BK (2017) On-line fresh-cut lettuce quality measurement system using hyperspectral imaging. Biosyst Eng, 156, 38-50

4. Sun Y, Zhang W, Zeng T, Nie Q, Zhang F, Zhu L (2015) Hydrogen sulfide inhibits enzymatic browning of fresh-cut lotus root slices by regulating phenolic metabolism. Food Chem, 177, 376-381

5. Gil MI, Selma MV, Lopez-Galvez F, Allende A (2009) Fresh-cut product sanitation and wash water disinfection: Problems and solutions. Int J Food Microbiol, 134, 37-45

6. Wang H, Feng H, Lue Y (2004) Microbial reduction and storage quality of fresh-cut cilantro washed with acidic electrolyzed water and aqueous ozone. Food Res Int, 37, 949-956

7. Economou KD, Oreopoulou V, Thomopoulos CD (1991) Antioxidant activity of some plant extracts of the family Labiatae. J Am Oil Chem Soc, 68, 109-113

8. Stojanovic R, Belscak-Cvitanovic A, Manojlovic V, Komes D, Nedovic V, Bugarski B (2012) Encapsulation of thyme (Thymus serpyllum L.) aqueous extract in calcium alginate beads. J Sci Food Agric, 92, 685-696

9. Perdones A, Chiralt, A, Vargas, M (2016) Properties of 
film-forming dispersions and films based on chitosan containing basil or thyme essential oil. Food Hydrocolloids, 57, 271-279

10. Cui H, Ma C, Li C, Lin L (2016) Enhancing the antibacterial activity of thyme oil against Salmonella on eggshell by plasma-assisted process. Food Control, 70, 183-190

11. Nickons AB, Athanassios LY, Kimitrios JF, Angela STG, Paschalis DF (1997) Effect of dietary thyme $n$ the oxidative stability of egg yolk. J Agric Food Chem, 45, 3711-3716

12. Krause EL, Ternes W (1999) Bioavailability of the antioxidative thyme compounds thymol and $\rho$-cymene-2, 3-diol in eggs. Eur Food Res Technol, 209, 140-144

13. Amarowicz R, Zegarska Z, Rafalowski R, Pegg RB, Karamac M, Kosinska A (2009) Antioxidant activity and free radical-scavenging capacity of ethanolic extracts of thyme, oregano, and marjoram. Eur J Lipid Sci Technol, 111, 1111-1117

14. Dolea D, Rizo A, Fuentes A, Barat JM, FernandezSegovia I (2018) Effect of thyme and oregano essential oils on the shelf life of salmon and seaweed burgers. Food Sci Technol Int, 24, 394-403

15. Khouya T, Ramchoun M, Hmidani A, Amrani S, Harnafi H, Benlyas M, Zegaouti YF, Alem C (2015) Anti-inflammatory, anticoagulant and antioxidant effects of aqueous extracts from Moroccan thyme varieties. Asian Pac J Trop Biomed, 5, 636-644

16. Jung JY, Shin SH, Choi JH, Jeong MC (2008) Browning and quality changes of fresh-cut iceberg lettuce by gas flushing packagings. Korean J Hortic Sci, 26, 406-412

17. Singleton VL, Orthofer R, Ramuela-Raventos RM (1999) Analysis of total phenols and other oxidation substrates and antioxidants by means of folin-ciocalteu reagent. Methods Enzymol, 299, 152-178

18. Rico, Martin-Diana AB, Frias JM, Henegan GT, Barry-Ryan C (2006) Effect of azone and calcium lactate treatments on browning and texture properties of fresh-cut lettuce. J Sci Food Agric, 86, 2179-2188

19. Yang Z, Zheng Y, Cao S (2009) Effect of high oxygen atmosphere storage on quality, antioxidant enzymes, and DPPH radical scavenging activity of Chinese bayberry fruit. J Agric Food Chem, 57, 176-181

20. Ministry of Food and Drug Safety. http://www. foodsafetykorea.go.kr/foodcode/01_03.jsp?idx =362 (accessed August 2017)

21. Moon KD, Kim DH, Kim HB (2013) Effects of phytoncide treatment on the physiochemical, microbiological, and sensory characteristics of fresh-cut lettuce. Korean J Food Preserv, 20, 166-172

22. Kim JG, Choi ST, Lim CI (2005) Effect of delayed modified atmosphere packaging on quality of fresh-cut iceberg lettuce. Korean J Hortic Sci Technol, 23, 140-145

23. Lopez-Galvez G, Saltveit ME, Cantwell MI (1996) The visual quality of minimally processed lettuce stored in air or controlled atmospheres with emphasis on romaine and iceberg types. Postharvest Biol Technol, 8, 179-190

24. Lana MM, Tijskens LMM (2006) Effect of cutting and maturity on antioxidant activity of fresh-cut tomatoes. Food Chem, 97, 203-211

25. Ke D, Saltveit ME (1989) Wound-induced ethylene production, phenolic metabolism and susceptibility to russet spotting in iceberg lettuce. Physiol Plant, 76, 412-418

26. Kang HM, Saltveit ME (2002) Antioxidant capacity of lettuce leaf tissue increases after wounding. J Agric Food Chem, 50, 7536-7541

27. Rico D, Martin-Diana AB, Barat JM, Barry-Ryan C (2007) Extending and measuring the quality of fresh-cut fruit and vegetables: a review. Trends Food Sci Technol, 18, 373-386

28. Ryu JM, Park YJ, Choi SY, Hwang TY, Oh DH, Moon KD (2003) Brown inhibition and quality characteristics of minimally processed mushroom (Agricus bisporus Sing) using extracts from natural materials during storage. Korean J Food Preserv, 10, 11-15

29. Kim DH, Kim SM, Kim HB, Moon KG (2012) Effects of optimized co-treatment conditions with ultrasound and low-temperature blanching using the response surface methodlogy on the browning and quality of fresh-cut lettuce. Korean J Food Preserv, 19, 470-476

30. Bagamboula CF, Uyttendaele M, Debevere J (2004) Inhibitory effect of thyme and basil essential oils, carvacrol, thymol, estragol, linalool and p-cymene towards Shigella sonnei and S. flexneri. Food Microbiol, $21,33-42$

31. Singh N, Singh RK, Bhunia AK, Stroshine RL (2002) Efficacy of chlorine dioxide, ozone, and thyme essential oil or a sequential washing in killing Escherichia coli O157:H7 on lettuce and baby carrots. LWT-Food Sci Technol, 35, 720-729

32. Koseki S, Itoh K (2002) Effect of nitrogen gas packaging on the quality and microbial growth of fresh-cut vegetables under low temperatures. J Food Protect, 65, 326-332 